\title{
Infrequent p53 Gene Mutations and Lack of p53 Protein Expression in Clear Cell Sarcoma of the Kidney: Immunohistochemical Study and Mutation Analysis of p53 in Renal Tumors of Unfavorable Prognosis
}

\author{
Chuen Hsueh, M.D., Hao Wang, Ph.D., Frank Gonzalez-Crussi, M.D., Jer-Nan Lin, M.D., \\ Iou-Jih Hung, M.D., Chao-Ping Yang, M.D., Tang-Her Jiang, M.D. \\ Department of Pathology (CH), Department of Surgery (JNL) and Department of Pediatrics (IJH, CPY, \\ THJ), Chang Gung Children's Hospital, Tao Yuan, Taiwan, R.O.C.; and Department of Pathology, \\ Children's Memorial Hospital, Northwestern University (HW, FGC), Chicago, Illinois
}

\begin{abstract}
A high prevalence of $\mathrm{p53}$ gene mutation and protein expression has been found in the anaplastic variant of Wilms' tumor (WT), known to be associated with poor outcome. However, there are very few studies of p53 alterations in the other two rare and highly malignant renal tumors in childhood, in other words, clear cell sarcoma of the kidney (CCSK) and malignant rhabdoid tumor of the kidney (MRTK). Overexpression of $\mathrm{p53}$ protein has been detected in eight CCSKs in one study, and in two in another, yet no molecular correlation with p53 gene mutations has been carried out. Our study is the first molecular analysis concerning $\mathbf{p 5 3}$ in CCSK. We investigated eight cases of CCSK and one case of MRTK for p53 protein expression by immunohistochemical staining. All were analyzed for $\mathrm{p53}$ mutations in the region of exons 4 to 8 by polymerase chain reactionsingle-strand conformational polymorphism (PCRSSCP) method and DNA sequencing analysis. By histological study, no CCSK showed anaplastic features. None expressed p53 protein, but two harbored p53 mutations. One was in exon 5, with a base pair insertion between codons 162 to 163 causing frameshift alteration in amino acid. Another was a silent CTC $\rightarrow$ CTT transversion in codon 289 of exon 8. The case of MRTK did not show any alterations of p53 protein or gene. Our result indicates that p53 alterations are infrequent in CCSK and do not seem
\end{abstract}

Copyright (C) 2002 by The United States and Canadian Academy of Pathology, Inc.

VOL. 15, NO. 5, P. 606, 2002 Printed in the U.S.A.

Date of acceptance: January 22, 2002.

Supported by Grant NSC85-2331-B-182A-016 from the National Science Council of the Republic of China and Grant NMRP685 from Chang Gung Medical Research Fund, Republic of China.

Address reprint requests to: Chuen Hsueh, M.D., Department of Pathology, Chang Gung Children's Hospital, 5 Fu Shin Street, Kuei Shan, TaoYuan, Taiwan, R.O.C.; e-mail: ch9211@adm.cgmh.org.tw; fax: +886-3328-0147. to be primary genetic events in the pathogenesis of CCSK.

KEY WORDS: Anaplastic, Clear cell sarcoma of the kidney, Malignant rhabdoid tumor of the kidney, p53, Wilms' tumor.

Mod Pathol 2002;15(5):606-610

Clear cell sarcoma of the kidney (CCSK) and malignant rhabdoid tumor of the kidney (MRTK) are uncommon malignant renal tumors in childhood. CCSK comprises $4-5 \%$ of all pediatric renal tumors. The incidence peaks around 2 to 3 years of age. It has an aggressive biological behavior and a propensity for bony metastases (1-3). But the prognosis has been considerably improved since the addition of doxorubicin to the chemotherapeutic regimen (3). MRTK accounts for $2 \%$ of all renal tumors in children. Most patients are $<1$ year of age. The tumor has a dismal prognosis and a tendency for early dissemination (4). Mutations of p53 gene have been associated with a poor prognosis in a number of adult malignant tumors (5). Such association has also been found in several pediatric solid tumors, including rhabdomyosarcoma, glioma, and Wilms' tumor (WT; 6-9). Especially in the anaplastic variant of WT, p53 protein accumulation and gene mutations have been frequently detected (8-15). However, the available data on p53 gene mutations in CCSK and MRTK are very limited. Only three studies on p53 protein expression by immunohistochemistry have been reported $(3,16,17)$. Yet no molecular investigation for p53 mutations was carried out in these cases. Two recent studies by comparative genomic hybridization (CGH) in CCSK revealed a number of genetic abnormalities in which loss of chromosome17 was detected in one case (18, 19). Therefore, it is essential to clarify the role of p53 mutations in the pathogenesis of CCSK. Here, 
we report the first molecular analysis of p53 in CCSK. Exons 4 through 8 of the p53 gene were examined in eight CCSKs and one MRT by polymerase chain reaction-single-strand conformational polymorphism (PCR-SSCP) analysis and DNA sequencing. p53 protein expression was studied by immunohistochemical staining.

\section{MATERIALS AND METHODS}

Eight cases of CCSK and one case of MRTK diagnosed at Chang Gung Memorial Hospital between 1979 and 1995 were retrieved from the archives of the Department of Pathology. Clinical follow-up data of each case were obtained from the medical records. All cases were reviewed histologically to confirm the diagnosis. The immunohistochemical staining for p53 was performed on formalin-fixed, paraffin-embedded tissue of all cases using a peroxidase-labeled streptavidin biotin kit (DAKO). The primary antibodies used included a polyclonal antibody, CM1 (Novocastra, dilution 1:50), and a monoclonal antibody, DO7 (Novocastra, dilution 1:100). Both antibodies identify wild and mutant forms of human p53 protein. Only unequivocal diffuse nuclear staining ( $>75 \%$ of the nuclei) was considered as positive reaction. A case of anaplastic WT with p53 gene mutation in exon 8 confirmed by SSCP was used as positive control. The definition for anaplasia in WT included the presence of hyperchromasia, atypical mitoses, and enlarged nuclei more than three times larger than those of adjacent tumor cells (3). We used the same criteria for defining anaplastic CCSK.

\section{DNA Isolation and Polymerase Chain Reaction}

One block of each case that contained only tumor tissue was selected. Depending on the size of the tumor, two or three $10-\mu \mathrm{m}$ sections were cut from each sample. For each block, a new microtome knife blade was used, and sections were put in sterile tubes using tweezers that were washed in xylene between the sectioning of each block. DNA was extracted according to a standard method (20). Sections were dewaxed in a series of octane or xylene, washed twice with $100 \%$ ethanol to remove the solvent, and dried at room temperature. There was $200 \mu \mathrm{L}$ of extraction buffer (consisting of 100 mM Tris and $1 \mathrm{~mm}$ EDTA, $\mathrm{pH}$ 8.0, and proteinase $\mathrm{K}$ at concentration of $400 \mu \mathrm{g} / \mathrm{mL}$ ) added to the dried sample. Samples were incubated overnight at $55^{\circ} \mathrm{C}$ and boiled the following day for 7 minutes, then centrifuged at 13,000 rpm for 5 minutes, after which DNA was found in the supernatant. Genomic DNA (10-100 ng) was added to $50 \mu \mathrm{L}$ of solution containing $10 \mathrm{~mm}$ of Tris- $\mathrm{HCl}, \mathrm{pH} 8.3 ; 50 \mathrm{~mm}$ of potassium chloride; $1.5 \mathrm{~mm}$ of magnesium chloride; 0.5 $\mu \mathrm{M}$ each of upstream and downstream primers; 0.2 mM dNTP; and $1 \mathrm{U}$ of Taq DNA polymerase. After heating at $95^{\circ} \mathrm{C}$ for 5 minutes, the mixture was subjected to 35 cycles of denaturation for 1 minute at $94^{\circ} \mathrm{C}$; annealing for 1 minute at $56^{\circ} \mathrm{C}$ (exon 8), $58^{\circ} \mathrm{C}$ (exon 5), or $62^{\circ} \mathrm{C}$ (exon 4,6 , and 7 ); and extension for 2 minutes at $72^{\circ} \mathrm{C}$. After the last cycle, the reaction was maintained at $72^{\circ} \mathrm{C}$ for 10 minutes and storage of the PCR products at $4^{\circ} \mathrm{C}$. Sequences of p53 primers used for PCR were shown as in Table 1. Exons 4 and 7 were selected as described by Dahiya et al. (21), and exons 5, 6, 8 were selected as described by Takeuchi et al. (12).

\section{Single-Strand Conformation Polymorphism} Analysis and DNA Sequencing

Amplification polymerase chain reaction (PCR) products were diluted 1:10 in single-strand conformation polymorphism analysis (SSCP) buffer (95\% formamide, $20 \mathrm{~mm}$ ethylenediamine tetraacetic acid (EDTA), 0.05\% bromphenol blue, 0.05\% xylene cyanol, $0.1 \%$ sodium dodecyl sulfate (SDS), and 20 mm sodium hydroxide), denatured for 5 minutes at $98^{\circ} \mathrm{C}$, and immediately chilled on ice for another 5 minutes. The samples were loaded onto $10 \%$ nondenaturing polyacrylamide gels, and electrophoresis was performed in TBE $(90 \mathrm{~mm}$ Tris, $90 \mathrm{~mm}$ boric acid, 2.5 mM EDTA) buffer for 2-3 hours in the cold room. Staining of the single- and double-stranded DNA was performed by 1:10,000 diluted SYBR Gold nucleic acid gel stain (Molecular Probes, Eugene, OR). Any extra band present in the sample was considered as positive for mutation. After the SSCP

TABLE 1. Sequences of p53 Primers Used for PCR

\begin{tabular}{llc}
\hline \multicolumn{1}{c}{ Exon } & \multicolumn{1}{c}{ 5' $^{\prime}-3^{\prime}$ Sequence } & Size of PCR Product (bp) \\
\hline 4 Sense & TGC ACC AGC AGC TCC TAC AC & 181 \\
4 Antisense & CAT GGA AGC CAG CCC CTC AG & 282 \\
5 Antisense & TCT GTT CAC TTG TGC CCT GAC TTT & 221 \\
6 Sense & ACC CTG GGC AAC CAG CCC TGT CGT C & \\
6 Antisense & CAG GGC TGG TTG CCC AGG GTC CCC A & 165 \\
7 Sense & ACT GAC AAC CAC CCT TAA CCC CTC C & \\
7 Antisense & CGT CTA GAG GCC TGT GTT GTC TCC & 236 \\
8 Antisense & CGG TCG ACG GTG GCA AGT GGC TCC & \\
\hline
\end{tabular}


analysis, we fractioned the PCR product by cutting the extra bands in the SSCP-positive samples in the gel, extracted the DNA from the gel, and reamplified them by PCR. Confirmation and characterization of the p53 mutations were obtained through nonradioactive sequencing. After purification of the PCR products (Gel Extraction Kit; QIAquick, Valencia, CA), direct sequencing was performed by cyclic PCR using BigDye terminator seq kit (Perkin-Elmer, Foster City, CA) and the Perkin-Elmer ABI377 automatic sequencing system.

\section{RESULTS}

The clinical findings of 8 cases of CCSK and 1 case of MRTK were summarized in Table 2. There were two patients (Cases 1 and 2) who had been diagnosed and treated as WT during early 1980s. The diagnosis was revised as CCSK after review in current study. One patient without any available follow-up data (Case 4) was a consultation case from an outside hospital. Histologically, all CCSKs contained no anaplastic areas. None of the tumor cells in the cases of CCSKs and MRTK showed any immunoreactivity to $\mathrm{p} 53$. Nine tumor samples from eight CCSKs (Cases 1 to 8) and one MRTK (Case 9) were examined for p53 mutations by a nonradioactive PCR-SSCP-sequencing analysis. Three samples were found to have p53 alterations by the SSCP method. One was located in exon 8 (Cases 7), one was in exon 5 (Case 6), and the other was in an intron upstream of exon7 (Case 4; Fig. 1). They were confirmed by direct DNA sequencing (Fig. 2), with the result shown in Table 3. Case 6 had a base pair insertion between codons 162 to 163 of exon 5, with a frameshift alteration in amino acid. Case 7 showed a $\mathrm{C} \rightarrow \mathrm{T}$ transversion in codon 289 of exon 8 without substitution of amino acid, and Case 4 demonstrated an $\mathrm{A} \rightarrow \mathrm{G}$ transition in the intron, upstream at the 9th base from codon 225 of exon 7 . PCR-SSCP and DNA sequencing were also performed on the genomic DNA samples extracted from the normal kidney tissue in paraffin blocks of

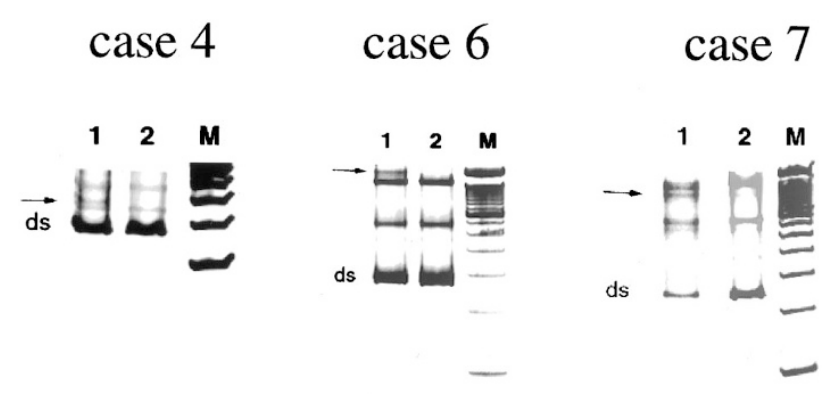

FIGURE 1. Polymerase chain reaction-single-strand conformational polymorphism analysis of p53 gene in clear cell sarcoma of the kidney tumor samples. Cases 4, 6, and 7 showed an extra band in PCR products from exons 7, 5, and 8, respectively. Lane 1, tumor sample. Lane 2, normal tissue. Lane M, 100-bp DNA ladder. ds = double-strand DNA. Arrow indicates the shift in single-strand DNA.

these patients. The base changes in Cases 6 and 7 were considered to be mutations, and in Case 4, these were considered natural polymorphisms of p53.

\section{DISCUSSION}

The information regarding p53 in childhood renal tumors of unfavorable histology, such as CCSK and MRTK, is remarkably scant. Only three studies on the expression of p53 protein in CCSK have been reported. The first report included a group of eight CCSKs, and all showed immunoreactivity to p53 protein, but no molecular evidence was provided (16). The second one was a case report of CCSK with intracranial metastasis, and p53 protein was not expressed in either the primary tumor or the metastatic lesion (17). The third report was from the National Wilms' Tumor Study Group containing 351 cases of CCSK, in which the existence of an anaplastic subset was well defined by Argani et al. (3) using the same criteria for anaplastic WT. Before that, the anaplastic pattern in CCSK was usually thought to be the effect of treatment (2). In their study, anaplasia in CCSK, as with WT, was considered to arise de novo. It is less common in CCSK

TABLE 2. Clinical Findings of Cases of CCSK and MRT

\begin{tabular}{|c|c|c|c|c|c|c|}
\hline Case & Age (yr)/Sex & Diagnosis & Kidney & $\begin{array}{l}\text { Clinical } \\
\text { Stage }\end{array}$ & Therapy & Outcome \\
\hline 1 & $1 / \mathrm{F}$ & CCSK & Right & I & $\mathrm{S}, \mathrm{CT}$ & No recurrence for 7 years \\
\hline 2 & $8 / \mathrm{M}$ & CCSK & Right & III & $\mathrm{S}, \mathrm{CT}, \mathrm{RT}$ & $\begin{array}{l}\text { Died } 21 / 2 \text { years later with liver and lung } \\
\text { metastases }\end{array}$ \\
\hline 3 & $18 / \mathrm{F}$ & CCSK & Left & II & $\mathrm{S}, \mathrm{CT}$ & No follow-up data available \\
\hline 4 & $7 / \mathrm{F}$ & CCSK & Right & III & $\mathrm{S}, \mathrm{CT}, \mathrm{RT}$ & No recurrence for 10 years \\
\hline 5 & $2 / \mathrm{M}$ & CCSK & Right & III & $\mathrm{S}, \mathrm{CT}, \mathrm{RT}$ & No recurrence for 9 years \\
\hline 6 & $2 \mathrm{mo} / \mathrm{M}$ & CCSK & Left & I & $\mathrm{S}, \mathrm{CT}$ & No recurrence for 7 years \\
\hline 7 & $4 / \mathrm{M}$ & CCSK & Left & II & $\mathrm{S}, \mathrm{CT}$ & $\begin{array}{l}\text { Died } 3^{1 / 2} \text { years later with bone and } \\
\text { lung metastases }\end{array}$ \\
\hline 8 & $12 / \mathrm{M}$ & CCSK & Right & II & S, CT & No recurrence for $3 \frac{1}{2} 2$ years \\
\hline 9 & Newborn/M & MRTK & Right & IV & $\mathrm{S}, \mathrm{CT}$ & $\begin{array}{l}\text { Died } 6 \text { months later with skin and lung } \\
\text { metastases }\end{array}$ \\
\hline
\end{tabular}

S, surgery; CT, chemotherapy; RT, radiotherapy. 
Case 4

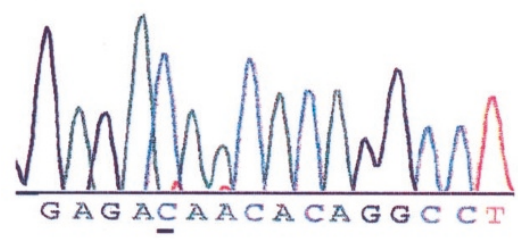

Case 6

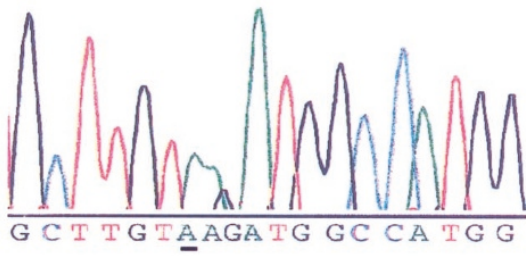

Case 7

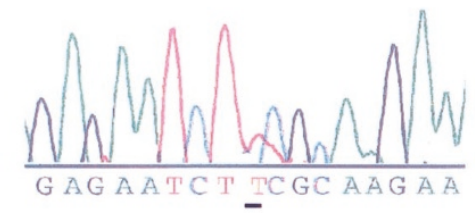

FIGURE 2. DNA sequencing analysis of p53 gene in tumor samples of clear cell sarcoma of the kidney. DNA sequencing revealed the following: an $\mathrm{A} \rightarrow \mathrm{G}$ transition, upstream 9th base from codon 225, in intron (Case 4), a T insertion between codons 162 and 163 (Case 6), and a C $\rightarrow \mathrm{T}$ transversion in codon 289 (Case 7). Cases 4 and 6 showed the sense strand of the p53 gene. Case 7 showed the antisense strand of the p53 gene.

TABLE 3. Molecular Results for p53 Mutations in CCSK Tumor Samples

\begin{tabular}{lcccccl}
\hline Sample & Exon & Nucleotide & Codon & Alteration & Base Pair Alteraction & \multicolumn{1}{c}{ Amino Acid Alteration } \\
\hline Case 4 & in intron & & & ts & A $\rightarrow \mathbf{G}$ & Upstream 9th base from codon 225 \\
Case 6 & 5 & $511 / 512$ & $162 / 163$ & is & $+(1) \mathbf{T}$ & Frame shift \\
Case 7 & 8 & 865 & 289 & tv & CTC $\rightarrow$ CTT & Silent \\
\hline
\end{tabular}

is, insertion; tv, transversion; ts, transition.

than in WT, with an incidence of $3 \%$. But its prognostic significance was unknown because the number of cases was too low. Nine out of 351 CCSKs showed anaplasia. There were 32 cases, including 29 non-anaplastic and 3 anaplastic CCSKs, stained for p53 protein. Intense and diffuse staining ( $>75 \%$ of the nuclei) was noted in 2 anaplastic CCSKs, but the non-anaplastic foci in these 2 tumors showed only minimal p53 staining ( $<5 \%$ of the nuclei), as did most of the non-anaplastic CCSKs. It is of particular interest that p53 staining was observed exclusively in the anaplastic areas. The finding was similar to anaplastic WT, which has a high frequency of p53 protein expression as a result of gene mutations. However, whether the presence of anaplasia in CCSK is related to p53 mutations and a poor prognosis remains uncertain.

None of our cases contained anaplastic areas, nor did they express p53 protein. Two cases presented with p53 mutation by PCR-SSCP analysis. DNA sequencing revealed insertion of a base pair between codons 162 to 163 of exon 5 with a frameshift alteration of amino acid in one (Case 6), and a silent $\mathrm{CTC} \rightarrow$ CTT transversion in codon 289 of exon 8 in another (Case 7). Case 6 was a Stage I patient who was alive and well 7 years after surgery, and Case 7 was a Stage II patient who died of the disease 3.5 years postoperation. It indicates that the occurrence of p53 mutations in CCSK is infrequent and may not be associated with a poor clinical outcome. The other case that showed an $\mathrm{A} \rightarrow \mathrm{G}$ transition in an intron upstream of exon 7 was considered as polymorphism. Our result is consistent with the previously reported absence of immunoreactivity to p53 in non-anaplastic CCSKs and further confirms the lack of p53 gene mutations in most of them at molecular level. As for the positive p53 staining in all 8 cases of CCSKs that was originally reported (16), it was most likely caused by the stabilization of wild-type p53 protein. Even if there had been any anaplastic subtype, the frequency of positive p53 staining should not be as high.

We have found p53 mutation in exon 5 in two non-anaplastic CCSKs. Although our study showed that p53 alterations are rare in CCSK, the possibility of their occurrence outside the conserved region cannot be completely excluded. The reported incidence of p53 mutations in anaplastic WT ranged from $25 \%$ to $73 \%$ (11-14). Whether it is the case in anaplastic CCSK remains to be investigated because no such case was present in our material.

A number of chromosomal alterations have been found in CCSK by comparative genomic hybridization (CGF) analysis $(18,19)$. The most common abnormality was the loss of $19 \mathrm{p}$. Others have been gain of 1q, loss of 16q, loss of 10q, and loss of 17 . The presence or absence of anaplasia in such cases has not been mentioned. Apart from the above example with loss of chromosome 17, which is the site where p53 is located, a reciprocal translocation between chromosomes 10 and 17 has been documented in another instance (22). These observations may imply a possible link of CCSK to p53. Variable chromosomal alterations have been associated with CCSK, indicating that the genetics of CCSK may be complex and that many genes may be involved in the development and progression of this tumor. Hence, we may suggest that p53 mutations do not seem to play a primary role in the tumorigenesis of CCSK. Nevertheless, further studies are warranted to draw a more definite conclusion.

Several malignant rhabdoid tumors of both renal and extrarenal origins have shown immunoreactiv- 
ity to p53 protein, which was confined to a small portion of the tumor (23-26). However, sequence analysis or Southern blotting of p53 gene did not reveal any mutation or amplification $(25,26)$. Our finding is in agreement with previous reports, but, in view of the paucity of cases studied thus far, it remains purely speculative to say that the p53 gene does not play a major role in the pathogenesis of MRTK.

\section{REFERENCES}

1. Sotelo-Avila C, Gonzalez-Crussi F, Sadowinski S, Gooch WM III, Pena R. Clear cell sarcoma of the kidney. A clinicopathological study of 21 patients with long-term follow-up evaluation. Hum Pathol 1985;16:1219-30.

2. Murphy WM, Beckwith JB, Farrow GM, editors. Tumors of the kidney, bladder, and related urinary structures. 3rd series, Fascicle 11. Washington, DC: Armed Forces Institute of Pathology; 1993. p. 76-80.

3. Argani P, Perlman EJ, Breslow NE, Browning NG, Green DM, D'Angio GJ, et al. Clear cell sarcoma of the kidney: a review of 351 cases from the National Wilms Tumor Study Group Pathology Center. Am J Surg Pathol 2000;24:4-18.

4. Weeks DA, Beckwith JB, Mierau GW, Luckey DW. Rhabdoid tumor of kidney. A report of 111 cases from the National Wilms' Tumor Study Pathology Center. Am J Surg Pathol 1989;13:439-58.

5. Hollstein M, Sidransky D, Vogelstien B, Harris CC. p53 mutations in human cancers. Science 1991;253:49-53.

6. Ayan I, Dogan O, Kebudi R, Bavbek B, Alatli C, Dervisoglu S, et al. Immunohistochemical detection of p53 protein in rhabdomyosarcoma: association with clinicopathological features and outcome. J Pediatr Hematol Oncol 1997;19:48 53.

7. Pollack IF, Hamilton RL, Finkelstein SD, Campbell J, Martinez AJ, Sherwin RN, et al. The relationship between p53 mutations and overexpression of p53 and prognosis in malignant gliomas of childhood. Cancer Res 1997;57:304-9.

8. Lahoti C, Thorner P, Malkin D, Yeger H. Immunohistochemical detection of p53 in Wilms' tumors correlates with unfavorable outcome. Am J Pathol 1996;148:1577-89.

9. Govender D, Harilal P, Hadley GP, Chetty R. p53 protein expression in nephroblastomas: a predictor of poor prognosis. Br J Cancer 1998;77:314-8.

10. Lemoine NR, Hughes CM, Ciwell JK. Aberrant expression of the tumour suppressor gene p53 is very frequent in Wilms' tumours. J Pathol 1992;168:237-42.

11. Bahtimi R, Hazen Martin DJ, Gian GR, Willingham MC Garvin AJ. Immunophenotype, mRNA expression, and gene structure of p53 in Wilms' tumors. Mod Pathol 1996;9:23844 .
12. Takeuchi S, Bartram CR, Ludwig R, Royer-Pokora B, Schneider S, Imamura J, et al. Mutations of p53 in Wilms' tumors. Mod Pathol 1995;8:483-7.

13. Bardeesy N, Falkoff D, Petruzzi MJ, Nowak N, Zabel B, Adam MC, et al. Anaplastic Wilms' tumour, a subtype displaying poor prognosis, harbours p53 gene mutations. Nat Genet 1994;7:91-7.

14. Malkin D, Sexsmith E, Teger H, Williams BRG, Coppes MJ. Mutations of the p53 tumor suppressor gene occur infrequently in Wilms' tumor. Cancer Res 1994;54:2077-9.

15. Waber PG, Chen J, Nisen PD. Infrequency of ras, p53, WT1, or RB gene alterations in Wilms' tumors. Cancer 1993;72: 3732-8.

16. Cheah PL, Looi LM. Implications of p53 protein expression in clear cell sarcoma of the kidney. Pathology 1996;28:22931.

17. Park DY, Kim YM, Chi JG. Intracranial metastasis from clear cell sarcoma of the kidney: a case report. J Korean Med Sci 1997;12:473-6.

18. Barnard M, Bayani J, Grant R, Zielenska M, Squire J, Thorner P. Comparative genomic hybridization analysis of clear cell sarcoma of the kidney. Med Pediatr Oncol 2000;34(2):113-6.

19. Perlman EJ, Schuster AE, Argani P, Beckwith JB, Grundy P, D'Angio GJ, et al. Genetic analysis of clear cell sarcoma (CCSK) by comparative genomic hybridization (CGH) [abstract]. Mod Pathol 1999;12:4P.

20. Shibata K. The polymerase chain reaction and the molecular genetic analysis of tissue biopsies. In: Herrington CS, McGee JO'D, editors. Diagnostic molecular pathology, a practical approach. Vol II. New York: Oxford University Press, Inc.; 1992. p. 85-111.

21. Dahiya R, Deng G, Chen KMK, Chui RM, Haughney PC, Narayan P. p53 tumour-suppressor gene mutations are mainly localized on exon 7 in human primary and metastatic prostate cancer. Br J Cancer 1996;74:264-8.

22. Punnett HH, Halligan GE, Zaeri N, Karmazin N. Translocation 10;17 in clear cell sarcoma of the kidney. A first report. Cancer Genet Cytogenet 1989;41:123-8.

23. Marcus VA, Viloria J, Owen D, Tsao MS. Malignant rhabdoid tumor of the colon: Report of a case with molecular analysis. Dis Colon Rectum 1996;39:1322-6.

24. Kaiserling E, Ruck P, Handgretinger R, Leipoldt M, Hipfel R. Immunohistochemical and cytogenetic findings in malignant rhabdoid tumor. Gen Diagn Pathol 1996;141:327-37.

25. Hirose M, Yamada T, Abe T, Hirose T, Shimizu E, Yamatomo $\mathrm{Y}$, et al. Establishment and characterization of two cultured cell lines derived from malignant rhabdoid tumors of the kidney. Int J Cancer 1996;67:218-23.

26. Rosson GB, Hazen-Martin DJ, Biegel JA, Willingham MC, Garvin AJ, Oswald BW, et al. Establishment and molecular characterization of five cell lines derived from renal and extrarenal malignant rhabdoid tumors. Mod Pathol 1998;11: $1228-37$. 